УДК 81`42

ББК 81.411.2-5

DOI: https://doi.org/10.17308/lic.2021.3/3573

\title{
КОННЕКТИКОН ТЕКСТА/КОРПУСА: ОПРЕДЕЛЕНИЕ ПОНЯТИЯ И МЕТОДИКА ОПИСАНИЯ
}

\author{
С. А. Чуриков \\ Воронежский государственный университет

\section{CONNECTICON OF THE TEXT/CORPORA: DEFINITION OF THE CONCEPT AND METHOD OF DESCRIPTION}

\author{
S. A. Churikov \\ Voronezh State University
}

\begin{abstract}
Аннотация: в статье обосновывается необходимость перехода от описания единичных межтекстовых связей и совокупностей только «входящих» или только «исходящих» интертекстовых заимствований к описанию всего комплекса интертекстовых связей отдельного текста или определенного множества текстов (корпуса). Под комплексом интертекстуальных связей отдельного текста Х автор понимает совокупность его связей: 1) с множеством текстов У, из которых данный текст заимствовал какие-либо элементы («входящие»), и 2) множеством текстов Z, которые заимствовали какие-либо элементь («исходящие») из данного текста. Комплекс интертекстуальных связей множества текстов Хпредставляет собой совокупность: 1) его связей с множеством текстов У, из которых тексты данного множества заимствовали какие-либо элементы, 2) его связей с множеством текстов $Z$, которые заимствовали какие-либо элементы из текстов данного множества, а также 3) интертекстовых связей между текстами данного множества. Такой комплекс предлагается называть термином «коннектикон», образованным по аналогии с терминами «лексикон», «ономастикон» и т. д. Разработанный автором вариант методики описания коннектикона корпуса включает в себя следующче шесть этапов работь: 1) предварительный этап; 2) сбор материала; 3) описание совокупности внутренних интертекстовых связей (эндоконнектем); 4) описание совокупности интертекстовых заимствований («входящих» экзоконнектем); 5) описание совокупности интертекстовых заимствований из описываемого корпуса («исходящих» экзоконнектем); 6) общая характеристика коннектикона корпуса.

Ключевые слова: интертекст, интертекстовая единица, коннектема, коннект, коннектикон, методика описания коннектикона текста/корпуса.
\end{abstract}

\begin{abstract}
: the article substantiates the need to move from the description of individual intertextual links and corpora of only "incoming" or only "outgoing" intertextual borrowings to the description of the entire complex of intertextual links of a single text or a certain set of texts (corpora). By the complex of intertextual relations of a single text $X$, the author understands the totality of its relations: 1) with the set of texts $Y$, from which the given text borrowed any elements ("incoming"), and 2) with the set of texts $Z$, which borrowed any elements ("outgoing") from this text. The complex intertextual relations to a variety of texts $X$ is a set: 1) the set of texts, of which texts are given many borrowed any elements, 2) the $Z$ set of texts, which borrowed some elements from the texts of the given set, and 3) intertextual relations between the texts of the given set. Such a complex is proposed to be called the term connecticon, formed by analogy with the terms lexicon, onomasticon, etc. The author's version of the method of describing the connecticon of a corpora includes the following six stages of work: 1) preliminary stage; 2) data collection; 3) description of a set of internal intertext connections (endoconnectemes); 4) description of a set of intertext borrowings ("incoming" exoconnectemes); 5) description of a set of intertext borrowings from the described corpora ("outgoing" exoconnectemes);6) general characteristics of connecticon of corpora.
\end{abstract}

(C) Чуриков С. А., 2021

Контент доступен под лицензией Creative Commons Attribution 4.0 License.

The content is available under Creative Commons Attribution 4.0 License. 
Key words: intertext, intertext unit, connecteme, connect, connecticon, methodology for describing the connecticon of a text/corpora.

\section{Введение}

Интертекст уже более полувека находится в центре внимания отечественных и зарубежных лингвистов, литературоведов, культурологов, семиотиков, философов. В последние десятилетия в этой области гуманитарных наук особенно интенсифицировались исследования теоретического характера: обсуждаются принципы и предлагаются методики интертекстуального анализа [1; 2 и др.], разрабатываются типологии интертекстуальных элементов [3; 4 и др.], предпринимаются попытки упорядочить и реформировать терминологию [5; 6 и др.], описываются особенности функционирования интертекстуальных единиц в текстах различных стилей и жанров [7; 8 и др.] и т. д. Наряду с большим количеством теоретических работ, значительная часть научной литературы посвящена анализу конкретного интертекстового материала. Работы второго рода можно с известной долей условности разделить на следующие группы:

1) описания отдельной интертекстовой единицы, представленной в тексте X [9 и др.];

2) описания функционирования отдельной интертекстовой единицы из текста Х в множестве текстов У [9 и др.];

3) описания интертекстуальных заимствований, представленных в отдельном тексте [10 и др.];

4) описания интертекстуальных единиц, восходящих к отдельному тексту Х [6 и др.];

5) описания интертекстуальных заимствований, представленных в определенном множестве текстов [11 и др.];

6) описания интертекстуальных единиц, восходящих к определенному множеству текстов (далее корпусу). Такого рода исследования активно ведутся, в частности, в рамках отечественной авторской лексикографии. За последние два десятилетия российскими лексикографами созданы словари крылатых выражений и цитат А. С. Пушкина [12 и др.], А. С. Грибоедова [13; 14], И. А. Крылова [15], А. В. Кольцова [16], И. С. Никитина [17] и многие другие.

\section{Определение понятия «коннектикон текста/корпуса»}

Анализ этого корпуса научных трудов, с одной стороны, показывает, что проведена колоссальная работа по выявлению и описанию интертекстуальных связей тысяч текстов различных стилей и жанров. С другой стороны, нетрудно заметить, что в представленной классификации отсутствуют работы, в кото- рых были бы предприняты попытки описания всего комплекса интертекстовых связей отдельного текста или определенного корпуса.

При этом под комплексом интертекстуальных связей отдельного текста Х мы понимаем совокупность его связей: 1) с множеством текстов У, из которых данный текст заимствовал какие-либо элементы («входящие»), и 2) с множеством текстов Z, которые заимствовали какие-либо элементы («исходящие») из данного текста.

Комплекс интертекстуальных связей корпуса $\mathrm{X}$ представляет собой совокупность: 1) его связей с множеством текстов У, из которых тексты данного корпуса заимствовали какие-либо элементы, 2) его связей с множеством текстов Z, которые заимствовали какие-либо элементы из текстов данного корпуса, а также 3) интертекстовых связей между текстами данного корпуса.

Ключевую роль в предложенных определениях играют термины «текст» и «интертекстовая связь», которые, как известно, по-разному трактуются учеными. Поэтому важно уточнить, что мы придерживаемся «широкого» подхода к трактовке объема этих понятий.

Под текстом мы понимаем «объединенную смысловой связью последовательность знаковых единиц» $[18$, с. 543], в том числе музыкальное сочинение, картину и т. д. С нашей точки зрения, именно такая широкая трактовка термина «текст» является наиболее продуктивной в сфере интертекстуальных исследований. Дело в том, что с древних времен шло активное взаимодействие произведений искусства разных типов: писатели включали в свои произведения отсылки к картинам, скульптурам, музыкальным сочинениям, композиторы, в свою очередь, использовали в своих произведениях цитаты из литературных текстов и т. д. (см., к примеру, большую подборку стихотворных эпиграфов к музыкальным произведениям в [19]). Из сказанного с неизбежностью вытекает, что, с разделяемой нами точки зрения, так называемые интермедиальные связи являются частным случаем связей интертекстовых.

Интертекстовыми единицами мы считаем «любые элементы текста или множества текстов X, которые были в том или ином виде заимствованы в текст или множество текстов У». Ранее в работе [20, с. 8] был предложен новый термин для наименования так понимаемых интертекстовых единиц - коннектема (от англ. connect - соединять(ся), связывать(ся), ассоциироваться). Данный термин в своей внутренней форме несет идею связи и создан по продуктивной 
для лингвистической терминологии модели (лексема, морфема, фонема и т. д.). Так же, как морфема реализуется в конкретных словах в виде одного из своих вариантов - морфов, так и коннектемы представлены в конкретных текстах в виде одного из своих вариантов, которые мы предлагаем называть коннектами.

Следует сказать, что в указанной выше статье автором была предпринята попытка построения исчисляющей классификации интертекстовых единиц, в основу была положена следующая триада параметров: 1) атрибутированность/неатрибутированность; 2) маркированность/немаркированность; 3) каноничность/трансформированность. Применение этой классификации показало, что парадигма единиц, составляющих коннектему, представляет собой множество из восьми базовых вариантов, которое образуется в результате применения к ее основному варианту следующих операций: 1) снятия атрибуции; 2) снятия маркировки; 3) трансформации. Перечислим эти типы:

1) атрибутированный, маркированный, канонический коннект;

2) атрибутированный, маркированный, трансформированный коннект;

3) атрибутированный, немаркированный, канонический коннект;

4) атрибутированный, немаркированный, трансформированный коннект;

5) неатрибутированный, маркированный, канонический коннект;

6) неатрибутированный, маркированный, трансформированный коннект;

7) неатрибутированный, немаркированный, канонический коннект;

8) неатрибутированный, немаркированный, трансформированный коннект.

Разные типы коннектов связаны с их реализацией в определенных текстовых позициях. С нашей точки зрения, существенное значение для функционирования коннектов имеют три текстовые позиции: 1) эпиграф; 2) заглавие; 3) «тело» текста. При этом именно позиция эпиграфа, специально предназначенная для размещения интертекстовых единиц, является сильной для коннектов, которые в большинстве случаев сохраняют здесь все характеристики текста-источника, снабжаются четкой атрибуцией и особым образом маркируются.

В русле формируемой нами терминосистемы описанный в начале настоящей статьи комплекс интертекстовых связей логично было бы называть термином, внутренняя форма которого также несет идею связи, точнее - совокупности связей. Таким термином может стать слово коннектикон, образованное по аналогии с терминами лексикон, ономастикон, антропонимикон и т. д. Используя предложенную терминологию, можно сказать, что коннектикон текста - это совокупность «входящих» и «исходящих» коннектем, а коннектикон корпуса - это совокупность внутренних коннектем (т. е. интертекстовых связей между текстами данного множества) и внешних коннектем (интерекстовых связей данного множества текстов с прочими текстами - «входящих» и «исходящих»). «Внутренние» коннектемы можно называть эндоконнектемами (др.-греч. है $\delta \delta \nu$ - «внутри»), а «внешние» коннектемы - экзоконнектемами

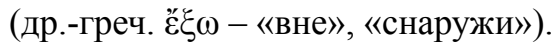

\section{Методика описания коннектикона текста}

Итак, коннектикон отдельного текста и тем более определенного корпуса может представлять собой весьма трудный для изучения объект. Поэтому для его корректного описания разумно использовать определенную методику. Ниже мы представим разработанный нами вариант методики описания коннектикона текста, включающей в себя пять основных этапов работы, каждый из которых делится на ряд подэтапов, часть из которых мы сопроводим более или менее развернутыми пояснениями.

\section{1. Предварительный этап.}

1.1. Сбор общих сведений об исследуемом тексте: наличие/отсутствие редакций и их количество, дата(ы) создания, дата первой публикации.

1.2. Сбор сведений о «вторичных» текстах (например, песнях, романсах, постановках, экранизациях и т. д.).

1.3. Формирование списка источников исследования, в который (разумеется, при наличии в них интересующих нас сведений) должны войти следующие группы текстов:

а) другие тексты данного автора, где он указывает на интертекстуальные связи изучаемого текста;

б) вступительные статьи и комментарии к изданиям данного автора;

в) параграфы и разделы учебных пособий;

г) лингвистические и литературоведческие работы;

д) словари и другие справочные издания;

е) прочие источники.

2. Сбор материала.

2.1. Отбор нужных сведений из работ, входящих в список источников.

2.2. Задание запросов с использованием «интертекстовых маркеров» в поисковых системах, лингвистических корпусах, электронных библиотеках и т. д. Интертекстовыми маркерами мы называем словосочетания и предложения, указывающие на то, что в текст вводится интертекстовый коннектор. Примерами таких маркеров могут служить следующие единицы: «как писал/написал/пишет X», «как говорил/ сказал X», «по словам $X$-а», «говоря словами $X$-а» и 
многие другие. Запросы с использованием интертекстовых маркеров помогают собрать примеры явного цитирования исследуемого текста.

2.3. Задание запросов, последовательно включающих каждое предложение, а в ряде случаев словосочетания и отдельные лексические единицы из данного текста, в поисковых системах, лингвистических корпусах, электронных библиотеках и т. д.

2.4. Задание запросов, последовательно включающих типичные варианты трансформаций отдельных предложений и словосочетаний, в поисковых системах, лингвистических корпусах, электронных библиотеках и т. д.

2.5. Опрос экспертов (специалистов по творчеству автора исследуемого текста).

3. Описание «входящих» коннектем и репрезентирующих их коннектов.

С нашей точки зрения, описание отдельной коннектемы должно включать в себя:

a) указание основного коннекта данной коннектемы;

б) этимологическую характеристику: указание на текст-источник/тексты-источники и автора/авторов;

в) указание репрезентирующего коннекта;

г) указание на позицию коннекта в принимающем тексте;

д) характеристику коннекта с точки зрения атрибутивности/неатрибутивности, маркированности/ немаркированности, каноничности /трансформированности;

е) указание на функцию (функции) в принимающем тексте.

4. Описание «исходящих» коннектем и репрезентирующих их коннектов.

См. предыдущий пункт.

5. Обобщающая характеристика коннектикона текста.

5.1. Характеристика корпуса «входящих» коннектем и репрезентирующих их коннектов, которая включает в себя:

а) характеристику корпуса текстов-доноров;

б) характеристику текстов-посредников (при их наличии); типу;

в) характеристику коннектов по структурному

г) характеристику коннектов по реализации в определенных текстовых позициях;

д) характеристику коннектов с точки зрения атрибутивности/неатрибутивности; маркированности/ немаркированности; каноничности/трансформированности;

е) описание основных функций «входящих» коннектов в изучаемом тексте.

5.2. Характеристика корпуса «исходящих» коннектем и репрезентирующих их коннектов. См. предыдущий подпункт.
Описание коннектикона корпуса должно включать в себя наряду с вышеперечисленными еще один этап - описание совокупности внутренних интертекстовых связей (эндоконнектем).

\section{Анализ коннектикона стихотворения \\ А. В. Кольцова «Лес» \\ (посвящено памяти А. С. Пушкина)}

Далее мы покажем (в сжатом виде) применение разработанной нами методики на примере анализа коннектикона стихотворения А. В. Кольцова «Лес» (посвящено памяти А. С. Пушкина). При этом рамки журнальной статьи заставляют нас ограничиться описанием связей этого текста только с произведениями художественной литературы.

1.1. Общие сведения. Как известно, знаменитое стихотворение «Лес» было написано А. В. Кольцовым в 1837 г. и является, по мнению ряда исследователей, одним из двух (наряду со «Смертью поэта» М. Ю. Лермонтова) наиболее значимых отзывов на гибель А. С. Пушкина. Произведение впервые напечатано в 1838 г. в журнале «Сын Отечества» (т. 2. С. 17-20). Варианты текста, представленные в указанной журнальной публикации, рукописи Дашкова (тетрадь II), рукописи князя Одоевского и статье А. Юдина (подробнее см.: [21]), мало отличаются друг от друга (варьируется небольшое число слов и словоформ) за одним, но крайне важным в контексте нашей темы исключением: в журнальном варианте имелся эпиграф (ниже мы еще вернемся к этому вопросу).

1.2. Сведения о «вторичных» текстах. Стихотворение «Лес» положено на музыку композиторами В. Прокуниным и Д. Усатовым.

1.3. Список источников. Сведения о некоторых «входящих» коннектемах интересующего нас произведения содержатся в монографии [22, с. 154-170]. Информация о ряде «исходящих» коннектем представлена в работах $[16$, с. $19,28,41,76,89,101,116$, $139 ; 23$, с. $81-85 ; 24$, с. $435-436 ; 25$, с. $54,63-64,73$, $79,84,90,99-100 ; 26$, c. $433 ; 27 ; 28$, c. $273 ; 29$, c. $79-$ $80]$.

2. Сбор материала (с использованием описанных выше приемов и инструментов) позволил сформировать корпус коннектов, включающий в себя 19 единиц разных типов.

3. «Входящие» экзоконнектемы и репрезентирующие их коннекты.

3.1. Коннекты, связывающие «Лес» с «овестью о Бове Королевиче».

Первым и очевидным коннектом является образ храброго витязя, Бовы-королевича, у Кольцова - богатыря Бовы, который, наряду с образом Леса, занимает центральное место в образной системе кольцовского шедевра. Как известно, А. В. Кольцов и 
А. С. Пушкин с детства знали это произведение, а последний еще и неоднократно использовал в своем творчестве образы, мотивы и цитаты из этого текста, о чем воронежский поэт, конечно же, знал.

Еще одним коннектом, связывающим «Лес» со знаменитой «Повестью», является мотив «нападения на / убийства спящего богатыря». В «Повести о Бове королевиче» этот мотив повторяется трижды: сначала дворецкий короля Зензевея Адаровича отдает приказ убить спящего Бову, но посланные дворецким храбрые витязи, испугавшись, отказываются от нападения; затем черноризец дает Бове усыпляющее зелье и обворовывает заснувшего под дубом героя, лишая его коня и меча-кладенца; наконец, на спящего у леса «брата» Бовы, богатыря Полкана, нападают львы и съедают заснувшего богатыря. В стихотворении А. В. Кольцова этот мотив представлен в преобразованном виде:

\section{Знать, во время сна \\ К безоружнному \\ Силь вражие \\ Понахлынули. \\ С богатырских плеч \\ Сняли голову - \\ Не большой горой, \\ А соломинкой...}

Таким образом, в данном случае мы имеем дело с неатрибутированным, немаркированным и трансформированным (замена компонентов) коннектом.

3.2. Коннекты, связывающие «Лес» со стихотворением А. С. Пушкина «Предчувствие» (1828).

Как уже было отмечено ранее, в первоначальной журнальной версии стихотворению «Лес» был предпослан эпиграф - первое четверостишие пушкинского «Предчувствия»:

\section{Снова тучи надо мною Собралися в тишине; \\ Рок завистливый бедою Угрожает снова мне...}

По неизвестным причинам составитель первого посмертного собрания сочинений воронежского поэта В. Г. Белинский снял данный эпиграф, а последующие издания поэзии А. В. Кольцова следовали этой традиции. Не обсуждая здесь правомерность решения выдающегося критика, отметим следующее. Во-первых, присутствие эпиграфа даже не в черновом, а в журнальном (!) варианте стихотворения обязывает нас учесть эту межтекстовую связь, указав на наличие атрибутированного, маркированного, канонического коннекта, отсылающего читателя к стихотворению А. С. Пушкина. Во-вторых, внимательное сравнение пушкинского и кольцовского стихотворений не оставляет сомнений, что связь между этими произведениями не ограничивается «пропавшим» эпиграфом: с нашей точки зрения, образы бури и тучи в «Лесе» также восходят к соответствующим образам, представленным в «Предчувствии». Ср. приведенное выше начало и следующий фрагмент стихотворения А. С. Пушкина:

$$
\begin{aligned}
& \text { Бурной жсизню утомленный, } \\
& \text { Равнодушно бури жду: } \\
& \text { Может былть, ещзе спасенный, } \\
& \text { Снова пристань я найду... }
\end{aligned}
$$

4. «Исходящие» экзоконнектемы и репрезентирующие их коннекты.

К настоящему времени удалось выявить следующие «исходящие» коннекты.

В рассказе И. С. Тургенева «Смерть» (1848) представлен атрибутированный, маркированный, канонический коннект «Где ж девалася // Речь высокая, // Сила гордая, // Доблесть царская? // Где же теперь твоя // Мочь зеленая?..» (наряду с коннектом того же типа, отсылающим к другому кольцовскому шедевру - «Думе сокола»).

В этом произведении писатель разворачивает перед нами целую галерею «удивительных смертей русских людей». Однако в начале рассказа изображается гибель не человека, а леса, которая заставляет автора вспомнить одноименное стихотворение А. В. Кольцова:

Лес Ардалиона Михайльчча с детства был мне знаком. Весь этот лес состоял из каких-нибудь двухили трехсот огромных дубов и ясеней. А что за тень в лесу была! Губительная, бесснежная зима 40-го года не пощуадила старых моих друзей-дубов и ясеней; засохиие, обнаженные, кое-где покрытые чахоточной зеленью, печально высились они над молодой рощей, которая «сменила их, не заменив»... Кто бь мог это предвидеть - тени, в Чапльгине тени нигде нельзя было найти! Что, думал я, глядя на умирающие деревья: чай, стылдо и горько вам?.. Вспомнился мне Кольиов:

\section{Где же девалася \\ Речь высокая, Сила гордая, Доблесть царская? \\ Где же теперь твоя Мочь зеленая?..}

Эти строки удивительно гармонично вплетаются в ткань тургеневского повествования. Ведь для А. В. Кольцова лес символизирует личность главного русского поэта - А. С. Пушкина. Тем самым И. С. Тургенев, цитируя эти строки, плавно переходит от темы смерти природы к теме смерти человека. При этом вдумчивый читатель понимает, что первой (хотя и не названной прямо) в тургеневском ряду удивительных смертей русских людей оказывается смерть А. С. Пушкина, о которой так проникновенно написал воронежский поэт (подробнее см.: [29]). 
В поэме Н. А. Некрасова «Кому на Руси жить хорошо» (1866-1874) (Глава 3. Пьяная ночь) обнаруживается неатрибутированный, немаркированный, трансформированный (усечение, замена компонента) коннект, отсылающий читателя к кольцовскому «Лесу» (ср. у Кольцова: С богатырских плеч // Сняли голову - // Не большой горой, // А соломинкой...):

\section{Встречал ты мужика \\ После работы вечером? \\ На пожне гору добрую \\ Поставил, съел с горошину: \\ «Эй! богатырь! соломинкой \\ Сшибу, посторонись!»}

В рассказе «Книжка чеков (Эпизод из жизни недоимщиков)» (1873) Г. И. Успенского содержится целая группа коннектов, связывающих это произведение со стихотворением А. В. Кольцова. В эту группу входят образы леса (у Успенского в нескольких случаях замененного бором) и богатыря, тучи и бури (замененной на грозу), мотив противостояния леса-богатыря последним, а также маркированные кольцовские строки «вороти назад, держни около»:

И, словно сказочный богатырь, наделенный непомерною силою денег, Иван Кузьмич начинает буквально двигать горами. Прикоснется он с своими капиталами к дремучему темному бору, грозно иумевшему тучам и грозам: «вороти назад, держи около», и с материнской заботливостью дававшему приют тысячам зверей и птиц, и-глядишь, в две-три недели после появления в этом лесу Ивана Кузьмича лес исчез, и уж больие нет этого дремучего богатыря! Разбежался зверь; с шумом, карканьем и плачем разлетелись птицы, и остались одни бревна, кое-где придавившие зайца, спасавшегося бегством, поленницы дров, брусья. А скоро и это исчезнет отсюда, и останется голое, изрытое место да деньги в кармане Ивана Кузьмича.

Комплекс кольцовских коннектов позволяет Г. И. Успенскому ярко показать «эпический» размах деятельности купца нового типа Ивана Кузьмича Мясникова, который не останавливается ни перед чем в погоне за деньгами и удовольствиями.

В романе И. Н. Потапенко «Не герой» (1891) содержится неатрибутированный, маркированный, канонический коннект - самые известные строки из кольцовского «Леса»: «Где жс девалася // Мочь зеленая, // Сила гордая, // Доблесть царская":

- А что? - продолжал Ползиков с тем же, по-видимому, принужденным смехом. - Не узнать? А? «Где ж девалася мочь зеленая, сила гордая, доблесть царская»? А? Эх, брат, наплевать!.. Все там будем!..

Сразу несколько интересующих нас коннектов обнаруживается в стихотворении С. Д. Дрожжина «Запевка» (1920). Во-первых, поэт заимствует из кольцовского произведения образ богатыря Бовы. Если А. В. Кольцов использовал этот образ для описания масштаба личности А. С. Пушкина, то С. Д. Дрожжин создает мощный образ народа-богатыря:

И стоит народ -
Богатырь Бова
Заколдованный,
На Руси стеной
Бьется с недругом
За свои права
Вековечные...

Во-вторых, С. Д. Дрожжин заимствует из «Леса» мотив противостояния богатыря «вражьим силам» и размер стихотворения воронежского поэта.

Рассмотренный выше яркий кольцовский образ богатыря Бовы обнаруживается также в стихотворении И. И. Савина «Я - Иван, не помнящий родства...» (1922-1927):

О земле, восставшей в лютом горе,

Грянет колокольная молва.

Стяг державный богатырь-Бова

Развернет на русском косогоре.

Известный воронежский писатель В. А. Кораблинов называет третью часть своего романа «Жизнь Кольцова» (1956) - «Осень черная». Это название (представляющее собой неатрибутированный, немаркированный, канонический коннект) отсылает читателя к известным строкам стихотворения «Лес»: Не осилили // Тебя сильные, // Так дорезала // Осень черная. В этой (завершающей) части романа В. А. Кораблинов описывает трагическую развязку жизни поэта, показывая, как эта «осень черная», которая, по образному выражению автора «Леса», погубила А. С. Пушкина, наступает и для самого Кольцова.

Наконец, в романе В. А. Смирнова «Открытие мира» (1947-1973) также представлены интересующие нас кольцовские строки (неатрибутированный, немаркированный, канонический коннект) - Вороти назад, // Держи около:

И вот здесь совесть сразу замолкала. Пардон-с, вороти назад, держи около! На ретивого коня не кнут, а вожжи надобньл.

5. Обобщающая характеристика коннектикона стихотворения «Лес».

Таким образом, коннектикон кольцовского «Леса» включает в себя пять «входящих» коннектов, связывающих его с «Повестью о Бове Королевиче» и пушкинским стихотворением «Предчувствие», один из которых представлен в позиции эпиграфа (фигурирующего в журнальной публикации, а затем снятого), а четыре (три образа и один мотив) - в «теле» текста.

Описываемый коннектикон кольцовского шедевра включает также 14 «исходящих» коннектов, свя- 
зывающих его с двумя стихотворениями («Я - Иван, не помнящий родства...» И. И. Савина и «Запевка» С. Д. Дрожжина) и поэмой Н. А. Некрасова «Кому на Руси жить хорошо?», двумя рассказами («Смерть» И. С. Тургенева и «Книжка чеков (Эпизод из жизни недоимщиков)» Г. И. Успенского), тремя романами («Не герой» И. Н. Потапенко, «Жизнь Кольцова» В. А. Кораблинова, «Открытие мира» В. А. Смирнова). Лишь один из перечисленных коннектов выступает в качестве заглавия (название третьей части романа В. А. Кораблинова), остальные представлены в «теле» текста. В структурном отношении корпус «исходящих» коннектов весьма разнороден: он включает как отдельные строки кольцовского «Леса», так и образы, мотивы, а также стихотворный размер. Большинство обнаруженных коннектов оказались неатрибутированными (исключение - «Смерть» И. С. Тургенева) и немаркированными (исключения «Книжка чеков» Г. И. Успенского, «Не герой» И. Н. Потапенко и уже упомянутый рассказ И. С. Тургенева) и непреобразованными (исключения - «Кому на Руси жить хорошо?» Н. А. Некрасова и «Книжка чеков» Г. И. Успенского).

\section{Заключение}

С нашей точки зрения, описание коннектикона отдельных произведений или их множеств позволит получить качественно новое знание о процессах и результатах взаимодействия текстов, а в перспективе даст возможность определить место отдельного текста или определенного множества текстов в интертекстуальном пространстве национальной (и шире мировой) культуры.

\section{ЛИТЕРАТУРА}

1. Москвин В. П. Методика интертекстуального анализа // Известия Волгоград. гос. пед. ун-та. 2015. № 3. C. $116-121$.

2. Интертекстуальный анализ : принципы и границы : сб. науч. ст. / под ред. А. А. Карпова, А. Д. Степанова. СПб. : Изд-во С.-Петерб. ун-та, 2018. 318 с.

3. Фатеева Н. А. Контрапункт интертекстуальности, или Интертекст в мире текстов. М. : Агар, 2000. 280 с.

4. Пьеге-Гро Н. Введение в теорию интертекстуальности : пер. с фр. / общ. ред. Г. Г. Косикова. Изд. 2-е. М. : Ленанд, 2015. 240 с.

5. Москвин В. П. Интертекстуальность : понятийный аппарат. Фигуры, жанры, стили. Изд. 3-е. M. : URSS, 2015. 168 c.

6. Сидоренко К. П. Цитаты из «Евгения Онегина» А. С. Пушкина в текстах разного жанра. СПб. : Образование, 1998. 316 с.

7. Бочарникова E. A. Проблемы классификации интертекстуальных включений в научном тексте // Вопросы когнитивной лингвистики. 2009. № 4. С. 97-105.
8. Интертекстуальность и фигуры интертекста в дискурсах разных типов : коллективная монография. М. : Наука-Флинта, 2016. 352 с.

9. Лотман Ю. М. Об одной цитате у Лермонтова // Лотман Ю. М. О поэтах и поэзии. Анализ поэтического текста. Статьи и исследования. Заметки. Рецензии. Выступления. СПб. : Искусство-СПб., 2001. С. 756-757.

10. Яковлев А. И. Интертекст в романе А. Белого «Петербург» : структура, семантика, функционирование : автореф. дис. ... канд. филол. наук : Ярославль, 2011. $23 \mathrm{c}$.

11. Семенова Н. В. Цитата в художественной прозе : на материале произведений В. Набокова. Тверь, 2002. $200 \mathrm{c}$.

12. Мокиенко В. М., Сидоренко К. П. Словарь крылатых выражений А. С. Пушкина. СПб. : Издательство СПбГУ ; Фолио-Пресс, 1999. 752 с.

13. Костомаров В. Г., Бурвикова Н. Д. Читая и почитая Грибоедова : крылатые слова и выражения. М. : Рус. яз., 1998. 79 с.

14. Мокиенко В. М., Семенеи О. П., Сидоренко К. П. Большой словарь крылатых выражений А. С. Грибоедова («Горе от ума»). М. : ОЛМА Медиа Пресс, 2009. 799 с.

15. Мокиенко В. М., Сидоренко К. П. Крылатые слова басен И. А. Крылова. СПб. : Издательство СПбГУ, 2018. $776 \mathrm{c}$.

16. Кольцчова Л. М., Чуриков С. А. Крылатое слово А. В. Кольцова. Опыт словаря. 2-е изд., испр. и доп. Воронеж : ИПЦ ВГУ, 2012. 182 с.

17. Кольцова Л. М., Чуриков С. А., Винтер М. В. Крылатое слово И. С. Никитина. Опыт словаря. Воронеж : ИД ВГУ, 2019. 152 с.

18. Лингвистический энциклопедический словарь / гл. ред. В. Н. Ярцева. М. : Сов. энцикл., 1990. 682 с.

19. Петров В. О. Светские тексты как основа эпиграфа в партитурах инструментальных произведений // Вестник Курган. гос. ун-та. Сер.: Лингвистика и межкультурная коммуникация. 2016. № 1. С. 115-119.

20. Чуриков C. A. Опыт построения исчисляющей классификации интертекстовых единиц // Вестник Воронеж. гос. ун-та. Сер.: Лингвистика и межкультурная коммуникация. 2020. № 4. С. 6-12.

21. Кольияов А. В. Полное собрание сочинений А. В. Кольцова. СПб., 1911. 471 с.

22. Скатов Н. Н. Сочинения : в 4 т. Т. 2. Алексей Кольцов. СПб. : Наука, 2001. 356 с.

23. Громов В. A. Кольцовские традиции и мотивы в «Записках охотника» И. С. Тургенева // Филологические записки. Серия литературы и фольклора. [Вып. 1]. Воронеж, 1971. С. 68-85.

24. Душенко $K$. В. Большой словарь цитат и крылатых выражений. М. : Эксмо, 2011. 1215 с.

25. Кольцова Л. М., Чуриков С. А. Поэтическое слово А. В. Кольцова в русской речи. Воронеж : ИПЦ ВГУ, 2013. $156 \mathrm{c}$.

26. Михельсон М. И. Ходячие и меткие слова. Сборник русских и иностранных цитат, пословиц, поговорок, 
пословичных выражений и отдельных слов. СПб., 1896. $600 \mathrm{c}$.

27. Сабик Э. В. К вопросу о преемственности литературных традиций в «Записках охотника» (И.С. Тургенев и А. В. Кольцов) // Филологические науки. 1961. № 2. С. $110-115$.

28. Тонков В. А. А. В. Кольцов : Жизнь и творчество. 2-е изд., перераб. и доп. Воронеж : Книгоиздат, 1958. $404 \mathrm{c}$.

29. Чуриков С. А. Цитаты из стихотворений А. В. Кольцова в русской художественной прозе XIX века // Вестник Воронеж. гос. ун-та. Сер.: Филология и журналистика. 2020. № 3. C. $78-81$.

\section{REFERENCES}

1. Moskvin V. P. Metodika intertekstual'nogo analiza [Intertextual analysis methodology]. In: Izvestiya Volgogradskogo gos. ped. un-ta. 2015. No. 3. Pp. 116-121.

2. Intertekstual'nyj analiz: principy i granicy: sbornik nauchnyh statej [Intertextual analysis: principles and boundaries: collection of scientific articles] / ed. by A. A. Karpov, A. D. Stepanov. St. Petersburg, Izd-vo SPbGU, 2018. $318 \mathrm{p}$.

3. Fateeva N. A. Kontrapunkt intertekstual'nosti, ili Intertekst $\mathrm{v}$ mire tekstov [Counterpoint of intertextuality, or Intertext in the world of texts]. Moscow: Agar, 2000. $280 \mathrm{p}$.

4. P'ege-Gro N. Vvedenie v teoriyu intertekstual'nosti [Introduction to the theory of intertextuality] / ed. by G. G. Kosikov. 2nd ed. Moscow: Lenand, 2015. 240 p.

5. Moskvin V. P. Intertekstual'nost': Ponjatijnyj apparat. Figury, zhanry, stili. [Intertextuality: Conceptual apparatus. Shapes, genres, and styles].3rd ed. Moscow: URSS, 2015. $168 \mathrm{p}$.

6. Sidorenko K. P. Citaty iz «Evgenija Onegina» A. S. Pushkina v tekstah raznogo zhanra [Quotes from «Eugene Onegin» by A. S. Pushkin in texts of different genres]. Saint Petersburg: Obrazovanie, 1998. 316 p.

7. Bocharnikova E. A. Problemy klassifikacii intertekstual'nyh vklyuchenij v nauchnom tekste [Problems of classification of intertextual inclusions in a scientific text]. In: Voprosy kognitivnoj lingvistiki. 2009. No. 4. Pp. 97-105.

8. Intertekstual'nost' i figury interteksta $\mathrm{v}$ diskursah raznyh tipov: kollektivnaya monografiya [Intertextuality and intertext figures in discourses of different types: a collective monograph]. Moscow: Nauka-Flinta, 2016. 352 p.

9. Lotman Yu. M. Ob odnoj citate u Lermontova [About one quote from Lermontov]. In: Lotman Yu. M. O poetah i poezii. Analiz poeticheskogo teksta. Stat'i i issledovaniya. Zametki. Recenzii. Vystupleniya. [About poets and poetry. Analysis of the poetic text. Articles and research. Notes. Reviews. Performances]. Saint Petersburg: Iskusstvo-SPb., 2001. Pp. 756-757.

10. Yakovlev A. I. Intertext in A. Bely's novel "Petersburg": structure, semantics, functioning [Intertekst v romane A. Belogo «Peterburg»: struktura, semantika, funkcionirovanie]: abstract. diss. of cand. of philol. sciences. Yaroslavl'. 2011. 23 p.
11. Semenova N. V. Citata v hudozhestvennoj proze: na materiale proizvedenij V. Nabokova [Quote in fiction: based on the works of V. Nabokov]. Tver', 2002. 200 p.

12. Mokienko V. M., Sidorenko K. P. Slovar' krylatykh vyrazhenii Pushkina [Dictionary of Pushkin's Winged Expressions]. St. Petersburg, Izdatel'stvo SPbGU; Folio-Press, 1999. $752 \mathrm{p}$.

13. Kostomarov V. G., Burvikova N. D. Chitaia i pochitaia Griboedova: Krylatye slova i vyrazheniia [Reading and Honoring Griboedov: Winged Words and Expressions]. Moscow: Russkii iazyk, 1998. 79 p.

14. Mokienko V. M., Semenets O. P., Sidorenko K. P. Bol'shoi slovar' krylatykh vyrazhenii A. S. Griboedova ("Gore ot uma") [Large Dictionary of Quo-tations by A. S. Griboedov ("Woe from Wit")]. Moscow: OLMA Media Press, 2009. 799 p.

15. Mokienko V. M., Sidorenko K. P. Krylatye slova basen I. A. Krylova [Winged Words from the Fables by I. A. Krylov]. St. Petersburg, Izd-vo SPbGU, 2018. 776 p.

16. Kol'cova L. M., Churikov S. A. Krylatoe slovo A. V. Kol'cova. Opyt slovarja [Flying word of A. V. Koltsov. An attempt at creating the dictionary]. 2nd ed. Voronezh: IPC VGU, 2012. $182 \mathrm{p}$.

17. Kol'cova L. M., Churikov S. A. Krylatoe slovo I. S. Nikitina. Opyt slovarja [Flying word of I. S. Nikitina. An attempt at creating the dictionary]. Voronezh: ID VGU, 2019. $152 \mathrm{p}$.

18. Lingvisticheskij enciklopedicheskij slovar' [Linguistic encyclopedic dictionary] / ed. by V. N. Yarceva. Moscow: Sov. encikl., 1990. 682 p.

19. Petrov V. O. Svetskie teksty kak osnova epigrafa v partiturah instrumental'nyh proizvedenij [Secular texts as the basis of the epigraph in the scores of instrumental works]. In: Proceedings of Kurgan State University. Series: Linguistics and Intercultural Communication. 2016. No. 1. Pp. 115-119.

20. Churikov S. A. An attempt at constructing an enumerative classification of intertextual units. In: Proceedings of Voronezh State University. Series: Linguistics and Intercultural Communication. 2020. No. 4. Pp. 6-12.

21. Koltsov A. V. Complete Works [Polnoye sobranie sochineny]. Saint Petersburg, 1911. $471 \mathrm{p}$.

22. Skatov N. N. Works in 4 Vols. Vol. 2. Aleksey Koltsov [Sochineniya v 4 t. T. 2. Aleksei Kol'tsov]. Saint Petersburg : Nauka, 2001. 356 p.

23. Gromov V.A. Kol'covskie tradicii i motivy v «Zapiskah ohotnika» I. S. Turgeneva [Koltsov's Traditions and Motifs in the «Notes of the Hunter» by I. S. Turgenev]. In: Filologicheskie zapiski. Seriya literatury i fol'klora. 1971. Issue 1. Pp. 68-85.

24. Dushenko K. V. Bol'shoi slovar' tsitat i krylatykh vyrazhenii. [Large Dictionary of Quotes and Winged Expressions]. Moscow, Eksmo. 1216 p.

25. Koltsova L. M., Churikov S. A. Poeticheskoe slovo A. V. Kol'tsova v russkoi rechi [Poetic Word of A. V. Koltsov in Russian Speech: A Monograph]. Voronezh, VSU, 2013. $144 \mathrm{p}$. 
26. Mihel'son M. I. Hodyachie i metkie slova. Sbornik russkih i inostrannyh citat, poslovic, pogovorok, poslovichnyh vyrazhenij i otdel'nyh slov [Winged and apt words. Collection of Russian and foreign quotations, proverbs, sayings, proverbial expressions and individual words.]. Saint Petersburg, 1896. 600 p.

27. Sabik E. V. K voprosu o preemstvennosti literaturnyh tradicij v «Zapiskah ohotnika» (I.S. Turgenev i A. V. Kol'cov) [On the question of the continuity of literary traditions in

Воронежский государственный университет

Чуриков С. А., кандидат филологических наук, доиент кафедры русского языка

E-mail: churikovsa@yandex.ru

Поступила в редакциюю 25 мая 2021 г.

Принята к публикаичи 15 июня 2021 г.

Для цитирования:

Чуриков С. А. Коннектикон текста/корпуса : определение понятия и методика описания // Вестник Воронежского государственного университета. Серия: Лингвистика и межкультурная коммуникация. 2021. № 3. C. 6-14. DOI: https://doi.org/10.17308/lic.2021.3/3573 the «Notes of the Hunter» (I. S. Turgenev and A.V. Koltsov)]. In: Filologicheskie nauki. 1961. No. 2. Pp. 110-115.

28. Tonkov V. A. Koltsov: Life and Creativite Work [A. V. Kol'tsov: Zhizn' i tvorchestvo]. 2-nd ed. Voronezh: Knigoizdat, 1958. 404 p.

29. Churikov S. A. Citaty iz stihotvorenij A. V. Kol'cova v russkoj hudozhestvennoj proze XIX veka [Quotes from poems by A. V. Koltsov in Russian fiction prose of the XIX century]. In: Proceedings of Voronezh State University. Series: Philology and Journalism. 2020. No. 3. Pp. 78-81.

Voronezh State University

Churikov S. A., Candidate of Philology, Associate Professor of the Russian Language Department

E-mail: churikovsa@yandex.ru

Received: 25 May 2021

Accepted: 15 June 2021

\section{For citation:}

Churikov S. A. Connecticon of the text/corpora: definition of the concept and method of description. Proceedings of Voronezh State University. Series: Linguistics and Intercultural Communication. 2021. No. 3. Pp. 6-14. DOI: https://doi.org/10.17308/lic.2021.3/3573 